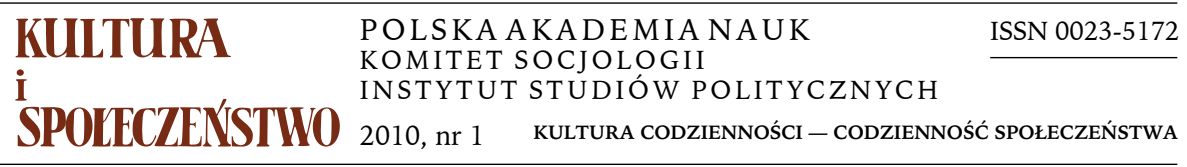

ŁUKASZ ROGOWSKI, RADOSŁAW SKROBACKI, DOROTA MROCZKOWSKA

Uniwersytet im. Adama Mickiewicza w Poznaniu

\title{
CODZIENNOŚĆ W KRYZYSIE
}

\section{CODZIENNOŚĆ I NIECODZIENOŚĆ JAKO FORMY ŻYCIA CODZIENNEGO}

Jednostki dążą do tego, aby w życiu codziennym doświadczać świata w formie rzeczywistości uporządkowanej, a przede wszystkim spójnej i przewidywalnej (por. np. Berger, Luckmann 1983; Goffman 2006a, 2006b; Manterys 1997). Jednak obok sfer porządku, umożliwiających praktyki bezrefleksyjne, a więc takie, które nie wymagają ciągłego sprawowania nad nimi kontroli, pojawiają się też takie, które stwarzają problemy lub przynajmniej wydają się problemowe, gdyż wymagają aktywności poznawczej i refleksji aktora. Zaden aktor społeczny nie jest przy tym w stanie monitorować strumienia swych doświadczeń w sposób wyczerpujący, sprawować kontroli nad całością swych przedsięwzięć, ani też w sposób efektywny odbierać i selekcjonować wszystkich dochodzących treści (zarówno bodźców, jak i informacji). Doświadczana przez jednostkę rzeczywistość ma zatem charakter hybrydowy, a jej dynamikę wyznacza ciągłe oscylowanie między sferami uporządkowanymi a tymi wymagającymi pracy porządkującej. Te dwie odmienne formy ontologicznego doświadczania, zwane przez nas codziennością i niecodziennością ${ }^{1}$, stanowią o treściach praktyk życia codziennego. Codzienność jest zatem pewnym sposobem doświadczania życia społecznego, opartym na wykorzystywaniu róż-

Adres do korespondencji: lukasz.rogowski@gmail.com; drmrocz@amu.edu.pl; radoslawskrobacki@interia.pl ków.

Łukasz Rogowski w roku akademickim 2009/2010 jest stypendystą Fundacji Rodziny Kulczy-

${ }^{1}$ Założenia te zbliżone są do teorii systemów autopojetycznych Niklasa Luhmanna. W odniesieniu do tej teorii codzienność byłaby odpowiednikiem systemu, a niecodzienność — środowiska systemu (por. Luhmann 2007, s. 23-24). 
nego rodzaju mechanizmów porząadkujących praktyki ${ }^{2}$. Charakteryzuje się tym samym bezrefleksyjnością i rutynowością, a zarazem zrozumiałością, intersubiektywnością i przekładalnością perspektyw (Schütz 1984, s. 147-150) ${ }^{3}$. Niecodzienność z kolei to te praktyki, które wyłamują się z rutyny, zaczynają być zauważalne i opisywalne, gdyż są nieuporządkowane, mają tym samym charakter problemowy i stawiają opór. Niecodzienność, w przeciwieństwie do codzienności, jest obmyślana, dzięki czemu ma moc wyznaczania granic.

Wykształcanie praktyk rutynowych, bezrefleksyjnych bądź nawykowych może być uznane za zasadniczy sposób porządkowania świata życia codziennego. Wszelkie implikujące nieporządek sytuacje problemowe natomiast wytrącają jednostki z rutyny codziennych czynności, schematów i doświadczeń, przymuszając niejako do przemyślenia istotnych aspektów egzystencji, zredefiniowania uznanej oczywistości czy podjęcia decyzji co do zmiany dotychczasowego sposobu życia. Są to takie momenty w biografii jednostki czy społeczeństw, które niosą za sobą poważniejsze następstwa, wywierają wpływ na późniejsze losy, a każdy taki przełom powoduje, iż jednostka musi stawić czoło nowemu, wiedząc, że dana strategia może być nieodwołalna (Giddens 2001, s. 155,276 i nast).

Codzienność i niecodzienność - mimo ontologicznych i epistemologicznych odrębności - są ze sobą nieodłącznie powiązane. Należy tym samym wskazać, iż ich wzajemna dynamika i swoistość zarazem (tym samym relacyjna odrębność) nie mają charakteru treściowego, a przynajmniej treść nie gra tu głównej roli, gdyż zasadnicza różnica dotyczy formy. Codzienność i niecodzienność to tym samym dwa różne sposoby doświadczania i realizowania życia codziennego, wynikające $z$ postrzegania jego praktyk jako odmiennych od siebie. Same w sobie nie mają one sprecyzowanej treści, nie składają się z konkretnych praktyk i zachowań, są natomiast formą wyznaczającą to, $\mathrm{w}$ jaki sposób wspomniane praktyki i zachowania są postrzegane i realizowane ${ }^{4}$. Innymi słowy, różnica między codziennością a niecodziennością nie jest różnicą empiryczną, ma raczej charakter ontologiczno-epistemologiczny i dotyczy jednostki bądź grupy, która w pewien sposób odnosi się do swego otoczenia. Mamy więc do czynienia z jednością nie tyle samej treści codzienności lub niecodzienności, ile raczej ich form - a więc sposobów doświadczania, interpretowania i realizowania praktyk życia codziennego.

$2 \mathrm{~W}$ poszczególnych partiach tekstu pojęcie codzienności będzie zyskiwać kolejne znaczenia, w zależności od poruszanego tematu. Należy pamiętać, iż nie są to znaczenia sprzeczne, ale raczej wzajemnie się uzupełniające lub uszczegóławiające omawiany kontekst.

3 Jest wszechogarniająca, „po prostu jest”, ,jest od zawsze”, na zasadzie „bo tak”.

4 Tezę tę można odnieść do rozważań Georga Simmla zawartych w Socjologii (2005, s. 17-18). 


\section{KRYZYS JAKO NARUSZENIE RELACJI CODZIENNOŚĆ-NIECODZIENNOŚĆ}

Zamierzamy teraz przyjrzeć się zjawisku kryzysu, a dokładniej temu, jak z perspektywy życia codziennego można go opisywać i interpretować. Takie ujęcie wydaje się tym bardziej istotne, że najczęściej stosowane w literaturze przedmiotu ujęcia kryzysu (w tym też klasyczne jego rozumienia) są rozpatrywane $z$ poziomu logiki procesów makrostrukturalnych ${ }^{5}$, co umniejsza istotę i znaczenie poziomów pozostałych. W klasycznych koncepcjach Durkheima, Mertona, Habermasa czy Luhmanna kryzys jest traktowany jako problem makrospołeczny i opisywany w zasadzie jako przejaw zaburzeń, pęknięć w relacjach pomiędzy makro- i mikrostrukturą czy napięć wynikających z rozbieżności między ofertami kierowanymi do jednostek i grup a aspiracjami, oczekiwaniami i sposobami postępowania tych jednostek i grup. Struktura czy system (w zależności od zastosowanej nomenklatury) rezygnuje $\mathrm{z}$ formułowania podpowiedzi działań jednostkowych (koncepcja Durkheima), utrudnia realizację konkretnych działań (koncepcja Mertona) bądź zawłaszcza Lebenswelt dla działań racjonalnych ze względu na cel, odmawiając tym samym działającym jednostkom prawa do samodzielnego decydowania o przebiegu własnych praktyk (koncepcja Habermasa). Cechą wspólną wskazanych podejść jest przyznawanie mocy sprawczej procesom makrostrukturalnym, zewnętrznie oddziałującym na jednostkowe strategie i praktyki dostosowawcze.

Podejście przez nas proponowane pozwala sprowadzić rozumienie kryzysu na poziom mikrospołeczny, tym samym jednostkom przypisać większe znaczenie $\mathrm{w}$ procesach jego wywoływania, podtrzymywania i przełamywania. Zdarzenie staje się kryzysem wtedy, gdy jako takie zacznie je percypować podmiot działający i gdy do takiej definicji dostosuje nie tylko treść, ale również formę swych codziennych praktyk. Kryzys zatem ma miejsce wtedy, gdy świat przyjmowany jako oczywisty (taken for granted) zostaje przez jednostkę poddany zwątpieniu lub gdy załamuje się funkcjonalność systemów typifikacji ${ }^{6}$

5 W literaturze socjologicznej, zarówno klasycznej, jak i współczesnej, można odnaleźć wiele koncepcji, które pośrednio lub bezpośrednio opisują i wyjaśniają zjawisko kryzysu. W koncepcji Émile'a Durkheima anomia - synonim kryzysu - to sytuacja, w której jednostki nie są w stanie rozpoznać, jakie postępowanie jest właściwe i jakie powinno być realizowane $\mathrm{w}$ konkretnych sytuacjach (Durkheim 1999, s. 447-497; por. też. Szafraniec 1986, s. 20-26). Według Roberta K. Mertona kryzys pojawia się, gdy system społeczny wymaga od jednostek realizowania pewnych praktyk lub przynajmniej definiuje pewne cele jako prawomocne, nie wyposażając jednak aktorów życia społecznego w odpowiednie środki umożliwiające osiągnięcie tych celów (Merton 1982, s. 196; Szafraniec 1986, s. 46-52). Z kolei według Jürgena Habermasa kryzys jest wynikiem procesu kolonizacji świata życia przez system; jest on tym większy, im bardziej media sterujące działaniami - władza i pieniądz — stają się elementem konstytutywnym działań komunikacyjnych (Habermas 2005, s. 383-401). Kryzys można również pojmować na przykład w kategoriach teorii Niklasa Luhmanna - jako sytuację, w której różne systemy autopojetyczne, o odmiennych kodach komunikacyjnych, odnoszą się do tej samej sfery życia społecznego.

${ }^{6}$ Najistotniejsze funkcje pełnione przez system typifikacji to: (1) wyznaczanie faktów, które powinny być brane pod uwagę przy wyznaczaniu typowych problemów, (2) wykształcanie ty- 
jako zasadniczych dla konstruowania możliwości (lub przynajmniej poczucia możliwości) przewidywania działań partnerów interakcji (zob. Schütz 1964, s. 261). Zgodnie $z$ takim rozumieniem, $z$ kryzysem mamy do czynienia wtedy, gdy postępowanie partnerów przestaje być dla jednostki przewidywalne, co załamuje zyskiwane dzięki funkcjonowaniu w codzienności poczucie bezpieczeństwa i stałości ${ }^{7}$. Tym samym kryzys nie dotyczy mnie dopóty, dopóki żywię graniczące z pewnością przekonanie, że partner interakcji postąpi tak, jak powinien postąpić zgodnie $z$ przewidywanymi schematami interakcji ${ }^{8}$. Na przykład załamanie finansowe nie ma przełożenia na codzienność (a tym samym nie jest pojmowane jako kryzys w przyjętym tutaj rozumieniu) dopóty, dopóki idąc do pracy mam pewność, że nie zostanę zwolniony (gdyż wypełniam sumiennie swoje dotychczasowe obowiązki), odwiedzając bank wiem, że nie odmówi mi on kredytu (gdyż spełniam wyznaczone przez tę instytucję warunki jego przyznania), a podczas zakupów na przykład ser nie będzie o wiele droższy niż dzień wcześniej.

\section{Poziomy uobecniania się kryzysu w codzienności}

O kryzysie możemy mówić, gdy rzeczywistość społeczna przestaje odpowiadać przewidywaniom, gdy staje się trudna do przyjęcia, bo pojawia się opór wynikający z niemożności przyjęcia oczywistych i prawdopodobnych do tej pory założeń. Kryzys zatem jest sytuacją zawieszenia, wnika w status quo naszej codzienności i na różne sposoby podważa jej dotychczasową logikę - wytwarzając swoiste kontinuum nowych sytuacji: od zaledwie chwilowego zaistnienia na poziomie codziennych rozmów aż po zasadniczą reorganizację formy życia codziennego.

Przykładem pierwszej sytuacji mogą być tzw. wojny na górze, często toczone i rozgrywane w instytucjach politycznych. Mamy wówczas do czynienia z pewnym faktem medialnym, który - jakkolwiek zauważalny i szeroko re-

powych motywów działań, (3) wykształcanie schematów interpretacji (Schütz 1964, s. 237-238).

7 Warto zwrócić uwagę na jeszcze jeden przykład kryzysu ugruntowanego na poziomie mikrospołecznym. Mamy tutaj na myśli różnego rodzaju „kryzysy interakcyjne”, których przykładem mogą być choćby Goffmanowskie fuszerki (Goffman 2006) czy etnometodologiczne poszukiwanie normalnej formy (Turner 2004, s. 480-494). Wynikają one najczęściej z braku odpowiednich kompetencji indywidualnych niezbędnych $\mathrm{w}$ bezproblemowym realizowaniu interakcji face to face (por. np. Goffman 2008). Kryzysy te, bez wątpienia istotne, nie znajdują się jednak w obszarze zainteresowań niniejszego tekstu. Mają one bowiem charakter sytuacyjny i nierzadko efemeryczny, nie wynikają z wzajemnych powiązań i oddziaływań sfery makro i mikro, lecz raczej z indywidualnych cech jednostki i umiejętności ich wykorzystywania w konkretnych sytuacjach.

8 Odwołajmy się więc do rozważań ze wstępu, gdy partner interakcji postąpi jak co dzień i przewidywalnie na poziomie formy („wiem, w jaki sposób będzie przebiegać jego działanie i jakie są jego motywy”), choć niekoniecznie treści („nie wiem dokładnie, w jaki konkretny sposób się zachowa"). 
lacjonowany - zasadniczo ma ograniczoną moc wpływania na codzienność osób bezpośrednio niezaangażowanych w ową sytuację. Do życia codziennego przedostaje się przez relacje medialne, a podtrzymywany jest $w$ rozmowach z członkami rodziny, przyjaciółmi czy kolegami z pracy. Jest to fakt codzienny nie ze względu na swoje cechy, ale dlatego że przynależny do pewnego typu faktów - nazwijmy je komentowanymi. W tym sensie zdarzenie $z$ poziomu makro, oraz jego znaczenie, sprowadza się do roli tematu dnia ${ }^{9}$.

Rozwinięciem owego zdarzenia mogą być bieżące komentarze, dotyczące na przykład sytuacji ekonomicznej. Przenoszą one relacje między kryzysem a codziennością na zupełnie inny poziom i ukazują skalę odpowiedzialności jednostki, która zmuszona jest wątpić w „zaklęcia” komentatorów: „Ekonomiści uspokajają: kryzys na razie dotyczy tylko instytucji finansowych, a nie całej gospodarki. Rodziny myślące $z$ niepokojem o swoich budżetach nie powinny więc - na razie — specjalnie obawiać się jego konsekwencji” ${ }^{10}$. W kilka dni później pojawiały się już zgoła odmienne informacje: „Polak znów musi rozglądać się za praca, bo ta przestała go szukać. Na rynku pracy szykuje się poważny kryzys, a polskie firmy zapowiadają ma sowe [podkr. autorzy] zwolnienia" 11 .

Przykładem trzeciej sytuacji, polegającej na zasadniczej reorganizacji codzienności, są niektóre „wydarzenia dnia”, wobec których nie możemy pozostać obojętni, wymagają bowiem od nas konkretnych działań w obszarze strategii adaptacyjnych (jak powyższe masowe bezrobocie). W tym ujęciu przemiany własnościowe i organizacyjne, dokonujące się na przykład w polskich stoczniach, dotykają nie tylko samych stoczniowców, ale również kooperujące ze stoczniami firmy z całego kraju (np. poznańskie Zakłady im. H. Cegielskiego), a ogólniej - wszystkie przedsiębiorstwa, i ich pracowników, które kiedykolwiek otrzymały państwową pomoc, a nie wywiązały się z ustalonych zobowiązań $^{12}$. Kryzys nie jest już tylko przyczynkiem do rozmów, ale staje się bodźcem do reagowania w obszarze własnych codziennych praktyk, na przykład przez oszczędzanie na wypadek utraty pracy czy ograniczenia dochodów, od-

9 Oczywiście, nie chcemy tu określać wielkości zbiorowości, dla której kolejna „wojna na górze” jest czynnikiem decydującym, mogącym wywołać konsekwencje istotne dla jej indywidualnego i społecznego kontekstu działania. Nie należy jednak spodziewać się, by każda tego typu batalia przynosiła doniosłe skutki społecznie w postaci zmian w obowiązujących formach codzienności.

10 A. Fandrejewska, Jak przetrwać ten kryzys , „Rzeczpospolita”, 27 września 2008 (http://www.rp. pl/artykul/19420,196618_Jak_przetrwac_ten_kryzys_html [18.01.2009]).

${ }_{11}$ Idzie kryzys na rynku pracy, TVN24, 1 października 2008 (http://www.tvn24.pl/-1,1566872,0,1, idzie-kryzys-na-rynku-pracy,wiadomosc.html [22.01.2009]).

12 Decyzja komisji $z$ dnia 06.XI.2008 r. w sprawie pomocy państwa $n r$ C 17/2005 (ex N 194/2005 i PL 34/2004) udzielonej przez Polskę Stoczni Gdynia (http://ec.europa.eu/competition/state_aid/ register/ii/doc/C-17-2005-WLAL-pl-06.11.2008.pdf); Decyzja komisji $z$ dnia 06.XI.2008 r w sprawie pomocy państwa nr C 19/2005 (ex N 203/05) udzielonej przez Polskę dla Stoczni Szczecińskiej (http://ec.europa.eu/competition/state_aid/register/ii/doc/C-19-2005-WLAL-pl-06.11.2008.pdf [18.01.2009]). 
roczenie konsumpcji niektórych dóbr czy usług ${ }^{13}$. Warto też zwrócić uwagę na „nowy wymiar” wewnętrznych relacji w polskich zakładach pracy, dokładniej: na relacji związki zawodowe-pracodawcy. Oto okazuje się bowiem, że organizacje pracownicze uczestniczą aktywnie w procesach dostosowywania zakładów pracy do obecnej sytuacji, co więcej - wypracowują wspólnie z pracodawcami zasady ograniczania czasu pracy czy wielkości wynagrodzeń ${ }^{14}$. Może to być źródło przyszłego przedefiniowania relacji pracodawca-pracownik, pamięć wzbogacona doświadczeniami kryzysu może podpowiadać nowe rozwiązania, nowe praktyki na czas po kryzysie.

\section{PRZEŁAMYWANIE KRYZYSU}

Kryzys powinien być zatem ujmowany całościowo, co oznacza rozpatrywanie go nie tylko pod względem tego, jak określa codzienność i wytwarza niecodzienność, ale także tego, jak owe elementy oddziałują zwrotnie na jego przebieg. Jeśli przyjmiemy, iż kryzys to nieprzewidywalność działań partnerów interakcji, to jednostka nie tylko go współwywołuje, lecz również jest zdolna do jego zażegnania czy przynajmniej częściowej likwidacji jego skutków. Owe działania mogą polegać zarówno na przywracaniu przewidywalności świata przez częściową neutralizację skutków kryzysu, jak i na wykształcaniu nowych sposobów doświadczania i realizowania codzienności. Ich efektem jest ucodziennianie (włączanie w obręb codzienności) nowych sytuacji i praktyk, a nie powrót do sytuacji sprzed kryzysu.

Neutralizowanie skutków kryzysu ma więc charakter podmiotowy i może być realizowane na dwa sposoby. Po pierwsze, może być efektem działania jednostki i stopniowego przyzwyczajania się do praktyk początkowo niecodziennych (bo nowych, a więc nierutynowych), z czasem zaś coraz bardziej codziennych (gdyż coraz mniej obmyśliwanych z racji stopniowego przyzwyczajania się do nich). Po drugie, może być podmiotowym wyborem źródła wyjaśniającego kryzys, a tym samym ukazującego, choć nie bezpośrednio, sposoby powrotu do codzienności.

\section{Odpowiedzialność jednostkowa w przełamywaniu sytuacji kryzysowych}

Przełomowość pewnych sytuacji przejawia się w tym, że stawiają jednostkę na rozdrożu, zmuszają do podjęcia decyzji, dokonania wyboru, a przede wszystkim do poznawczego i emocjonalnego opanowania i oswojenia nowych uwa-

\footnotetext{
13 Por. Reakcje na kryzys finansowy. Komunikat z badań, CBOS, Warszawa, grudzień 2008.

14 Idziemy po podwyżkę, a prezes mówi: Chłopy, trza ciać. Rozmawiała Małgorzata Buraja, „Gazeta Wyborcza”, 20 stycznia 2009 (http://wyborcza.pl/1,76842,6179390,Idziemy_po_podwyzke_a_ prezes_mowi_Chlopy_trza_ciac.html [22.01.2009]).
} 
runkowań, niekiedy podważają bowiem podstawy dotychczasowego bytu czy poczucia ontologicznego bezpieczeństwa. Momenty przełomowe nie są zatem incydentalnymi wydarzeniami zakłócającymi ciągłość i spokój doświadczania, ale procesami właśnie przez owe zdarzenia zapoczątkowanymi ${ }^{15}$. W ich wyniku dochodzi do częściowych bądź fundamentalnych przemian subiektywnej rzeczywistości, chociaż początkowo trudno odpowiedzieć na pytanie, czy zmiany są przejściowe czy będą obejmowały dłuższy okres życia jednostki ${ }^{16}$.

Moment przełomowy kwestionuje więc bezproblemowość jako cechę codzienności ${ }^{17}$. Jednostka musi zadać sobie pytanie - co jest/będzie dla niej większym problemem: (a) utrzymanie status quo kosztem zwiększonych nakładów (zarówno finansowych, na przykład muszę kupować droższe produkty, jak i pozafinansowych, na przykład muszę kogo innego obdarzać większym zaufaniem), czy (b) rezygnacja ze status quo i konieczność wykształcania nowych schematów typifikacyjnych (np. stale liczę się z tym, że mogę stracić pracę - współpracowników postrzegam więc jako potencjalnych wrogów/konkurentów).

Tym samym kryzys nie powinien być postrzegany jako stan, w którym znajdują się społeczeństwo i jednostki, lecz jako ciąg następujących po sobie i powiązanych zdarzeń - rezultatów podmiotowych decyzji jednostki, próbującej na różne sposoby zneutralizować sytuację, w jakiej się znalazła.

Wspomniany wcześniej przykład szybkiego wzrostu cen żywności stanowi przeniesienie na poziom życia codziennego sytuacji makrospołecznej, definiowanej, choćby przez media, jako kryzys ekonomiczny. Jednostka staje tym samym wobec konieczności wypracowania sposobów radzenia sobie z zaistniałą sytuacją i odbudowy załamanej stabilności. Dysponując różnymi możliwościami (kupowanie tych samych produktów i ponoszenie większych wydatków, rezygnacja z pewnych zakupów, zmiana kupowanych gatunków tych

15 Najczęściej doświadczamy sytuacji, które tak naprawdę nie są przełomowe, mają jedynie charakter informacyjny. Na przykład pracownik szpitala przekazuje uzyskaną w wyniku biopsji informację, czy guz jest złośliwy czy łagodny; owa informacja dopiero opatrzona refleksją może zdecydować o przełomie w życiu jednostki.

16 Sytuacje przełomowe mają zarówno pozytywne, jak i negatywne konsekwencje. Te pierwsze sprzyjają adaptacji do rzeczywistości, te drugie ową adaptacyjność podważają (z sytuacjami krytycznymi i kryzysami włącznie), co może stwarzać poczucie zerwania ciągłości biograficznej. Momenty przełomowe to także te sytuacje, w których jednostka odnajduje sens swojego życia lub które sprawiają, że gotowa jest w ogóle zwątpić w pomyślność jego przebiegu, gdyż czuje, że jakiekolwiek plany i przedsięwzięcia niczego nie wniosą.

$17 \mathrm{~W}$ celu rozwinięcia i uzupełnienia wcześniejszej definicji pojęcia codzienności warto dodać, iż codzienność może funkcjonować również jako forma kompromisu między maksymalizacją wyników a bezproblemowością. To sposób na wyrażanie odrębności (indywidualna kombinacja dążenia do maksymalizacji i bezproblemowości) oraz potwierdzenie przynależności (konsekwencją owych indywidualnych kombinacji są praktyki o jak najbardziej społecznych, ponadindywidualnych skutkach). Te dwa elementy — wyrażanie odrębności i potwierdzanie przynależności — są przykładami wspomnianych we wstępie mechanizmów porządkujących praktyki życia codziennego. 
produktów na tańsze, zmiana miejsca zakupów) może wybrać tę, która jest jej zdaniem — najkorzystniejsza.

Innym przykładem omawianej sytuacji może być korupcja i jednostkowe sposoby odnoszenia się do niej. W perspektywie makrospołecznej korupcja (jako odpowiednik kryzysu w ujęciu Habermasa, czyli wkraczania logiki systemu w Lebenswelt) jest wartościowana zdecydowanie negatywnie. Jednostka natomiast może rozumieć praktyki korupcyjne odmiennie — jako sposób radzenia sobie z zaistniałym wcześniej kryzysem ${ }^{18}$. Skoro bowiem służba zdrowia funkcjonuje źle (lekarz może odmówić konsultacji lub wyznaczyć odległą datę wizyty — jego działania są więc nieprzewidywalne), jednostka samodzielnie wypracowuje nowe formy poprawy własnej sytuacji - łapówka daje większą szansę na wizytę, a więc czyni działania pracowników służby zdrowia bardziej przewidywalnymi.

\section{Przeniesienie odpowiedzialności jako sposób na przełamanie kryzysu}

W procesie odbudowywania relacji między codziennością a niecodziennością częściej występuje jednak sytuacja przenoszenia odpowiedzialności na działania proponowane i/lub wykonywane przez innych. Pojawia się wówczas zasadnicze pytanie: czy i w jaki sposób w kontekście codzienności można mówić o władzy i w jaki sposób sytuacja kryzysowa władzę tę redefiniuje i zmusza do zastanowienia się nad jej istotą (specyfiką jej uzyskiwania, realizowania i myślenia o niej). W przeciwieństwie do sytuacji wcześniej opisywanej, w której jednostka samodzielnie, podejmując wysiłek porządkujący, odbudowywała sens i oczywistość praktyk życia codziennego, mechanizm porządkujący ma tu źródło nie tyle $\mathrm{w}$ jednostce, ile w szeroko rozumianych innych, którzy oferują różnego rodzaju wyjaśnienia oraz sposoby radzenia sobie z kryzysem. Dlatego zadaniem jednostki jest nie wypracowywanie konkretnych praktyk, lecz wybór najlepszych źródeł, z których wspomniane objaśnienia mają pochodzić. Działanie jednostki sprowadza się zatem do wyborów, którym towarzyszy zaufanie do danego źródła oraz przekonanie co do słuszności danego postępowania.

W tym rozumieniu władza to niejako siła perswazji, ponieważ ma ją ten, kto najlepiej tłumaczy, objaśnia, reinterpretuje codzienność, a tym samym likwiduje indywidualne napięcia i obawy związane z doświadczaniem kryzysu. Tak rozumiana władza jest więc przywilejem objaśniania codzienności uwikłanej w kryzys. Kto wyjaśnia codzienność, a tym samym na nowo porządkuje świat życia, zyskuje wpływ na kształtowanie praktyk jednostek w trakcie kryzysu i po nim. Takie rozumienie władzy różni się oczywiście zarówno od klasycznych jej definicji w socjologii, jak i od rozumienia instytucjonalnego. Po pierwsze, obja-

18 W tym kontekście jednostkowy sposób zażegnania kryzysu może mieć również aspekt samousprawiedliwiania własnych decyzji i realizowanych praktyk. 
śnianie codzienności nie musi być świadomym dążeniem do przeprowadzenia własnej woli. Wpływ na innych nie ma charakteru bezpośredniego i natychmiastowego, realizuje się $\mathrm{w}$ czasie przez powolne przyswajanie i internalizowanie otrzymywanych podpowiedzi. Po drugie, dość specyficzna sytuacja występuje również wtedy, gdy objaśnianiem codzienności zaczyna zajmować się władza instytucjonalna (np. politycy). Nie jest bowiem tak, że posiadający władzę instytucjonalną mają monopol na objaśnianie codzienności, co więcej, może być nawet tak, że taka władza $z$ góry postrzegana jest jako element niecodzienny ${ }^{19}$, bo wyobcowany, a tym samym mało kompetentny w zakresie rozumienia owej specyfiki. Doskonale fakt ten znajduje wyraz w tworzeniu opozycji „my” (społeczeństwo, obywatele, wyborcy) i „oni” (politycy, rządzący). „Oni” (a więc „nie-my”) to ci, którzy nie rozumieją „naszej” codzienności 20 .

Realizowanie władzy w warunkach likwidacji kryzysu jest zarezerwowane dla „ekspertów od codzienności”, a więc takich podmiotów, które jawią się jako kompetentne i godne zaufania - osób, które są zdolne do obłaskawienia skutków kryzysu przez pokazanie ich jako codziennych lub możliwych do realizowania w codzienności. Wręcz niesamowitej „sztuczki z kryzysem” dokonali amerykańscy spin doctors. Nawet niezbyt zaangażowany obserwator amerykańskiej kampanii prezydenckiej roku 2008 z pewnością poczynił dwa spostrzeżenia. Po pierwsze, dostrzegł to, że obaj główni kandydaci uczynili z kryzysu najważniejszy wątek kampanii wyborczej. Druga kwestia jest jeszcze ciekawsza - republikański kandydat bowiem długo twierdził, że kryzysu nie ma, później zaś, że amerykańska liberalna (dzięki republikanom, rzecz jasna) gospodarka łatwo sobie $z$ nim poradzi, gdy jednak oficjalnie przyznał, że problem istnieje, zalecił najbardziej nieliberalną z kuracji: wielkie programy wsparcia dla zagrożonego systemu finansowego. Amerykanie zamarli, dolar osłabł, republikanin przegrał. A jak z kryzysem poradził sobie sztab demokratów? Pomijając, że znajdował się w łatwiejszej sytuacji (kryzys zawsze można było przypisać ośmioletnim rządom republikanów), poszedł zdecydowanie dalej niż kontrkandydat. Zamiast zadowolić się zwykłą krytyką, uwypuklaniem różnic w planach wyjścia z kryzysu, demokraci skupili się na podkreślaniu wyjątkowości obecnych „czasów”. Zamienili dostatnią, szczęśliwą codzienność Ameryki przełomu wieków na trudną, ale dumną codzienność Ameryki czasów Baracka Obamy. Można zatem powiedzieć, że kryzys, który jawił się jako niemożliwy do przyswojenia w kontekście amerykańskiego dążenia do sukcesu, został w tę codzienność wpisany przez demokratów w sposób, który tej amerykańskiej

\footnotetext{
19 Barack Obama stwierdził: „Ludzie, którzy zbyt długo siedzą w Waszyngtonie, nie mówią jak zwykli ludzie”. „Wprost”, 25 stycznia 2009, s. 8.

20 Nie bez powodu po wygranych wyborach parlamentarnych w 2007 r. politycy Platformy Obywatelskiej zapowiadali „koniec Bizancjum”, a więc likwidację wielu zbędnych przywilejów i upodobnienie stylu życia władzy do stylu życia większości społeczeństwa http://fakty.interia.pl/ raport/nowy_rzad/news/schetyna-koniec-z-bizancjum,1015632,4944 [07.02.2009].
} 
codzienności w zasadzie nie narusza, czyli jako wyzwanie i szansa na sukces całego społeczeństwa. Codzienność cały czas ta sama, wypełniona dążeniem do sukcesu, tylko okoliczności inne. Obama, miast mówić o pieniądzu jako tym medium komunikowania, które w czasach kryzysu ekonomicznego zdaje się czymś najważniejszym, odwołał się do dumy, solidarności i wygrał, bo pozwolił Amerykanom nie zmieniać preferowanej wizji siebie, Ameryki i jej miejsca w świecie. Forma pozostała, treść jak zawsze zależy od faktów. Jesteśmy łasi na wygodę, bezproblemowość i taką codzienność kreujemy, w takiej czujemy się swobodnie. Ten zatem, kto - jak Obama - objaśni nowe okoliczności i nie zaneguje dotychczasowej codzienności, zyska władzę. Swoiste ucodziennianie niecodzienności jawi się tutaj zatem jako droga do władzy.

Rolę ekspertów od codzienności mogą również pełnić osoby, z którymi mamy $\mathrm{w}$ życiu codziennym bliski, bezpośredni kontakt — rodzina, sąsiedzi, współpracownicy. Po pierwsze, nawet w sytuacji pozakryzysowej mogą oni selekcjonować informacje i dostarczać te, które są najistotniejsze (zięć ekonomista-bankowiec doradzi w sprawie kredytu mieszkaniowego, szwagier pomoże wybrać samochód, sąsiadka podpowie wybór najkorzystniejszej oferty w sklepie komputerowym lub wytłumaczy skomplikowaną sytuację polityczna) ${ }^{21}$. Po drugie - i chyba ważniejsze - ekspert od codzienności może również stanowić dla jednostki pretekst do usprawiedliwiania własnych decyzji. Odpowiedzialność można w takim przypadku zrzucić na innych — bądź jasno określonych („pani Krysia mi powiedziała, że...”), bądź uogólnionych („wszyscy tak robią...").

W większości opracowań naukowych i w potocznych opiniach kryzys jest opisywany według trzech kryteriów. Po pierwsze, jest postrzegany w kategoriach negatywnych - jako zagrożenie, niepewność jutra. Po drugie, traktuje się go raczej jako stan i skutek pewnych wcześniejszych zdarzeń niż proces. Po trzecie, kryzys jest wyłomem w normalności i trwaniu, jest czymś nadzwyczajnym i rzadkim.

Przyjęta przez nas perspektywa rozumienia codzienności i niecodzienności pozwala w nowy sposób spojrzeć na owe przekonania. Jak wspominaliśmy, rutynowość i przewidywalność życia codziennego umożliwiają wzięcie w nawias serii trudnych pytań o samego siebie, innych i otaczającą rzeczywistość. Wszelkie kryzysy zaś - najczęściej w różnym stopniu zagrażające kokonowi ochronnemu - zarówno sprzyjają szukaniu oparcia w utrwalonych poglądach i ustalonych autorytetach, jak i mogą stanowić swoiste wyzwanie, okazję do

${ }^{21}$ Nie jest $\mathrm{w}$ tym przypadku istotne to, jakich działań dotyczy pomoc ekspertów (to znaczy czy są one codzienne czy niecodzienne ze względu na swoją treść), lecz raczej o to, że samo zwracanie się o pomoc ma charakter codzienny (ze względu na formę). 
nabycia nowych podstaw działania. Przerwanie ciągłości i spójności doświadczania skłania bowiem jednostki do posługiwania się procedurami uwiarygodnienia, do sięgnięcia po techniki, które instrumentalnie nakierowane są na podtrzymanie definicji rzeczywistości, bądź do ponownego odnalezienia społecznej matrycy obowiązujących znaczeń. Takie zabiegi poddaliśmy tu oglądowi, zakładając, że kryzys jest nieodłącznym elementem życia codziennego (które oscyluje między dwoma sposobami jego realizowania: codziennością i niecodziennością), a jego doświadczanie i radzenie sobie z nim traktując jako pośredni wskaźnik poziomu motywacji czy refleksji aktorów społecznych.

Przyjęcie takiej perspektywy wydaje się się istotne z kilku powodów. Po pierwsze, kryzys jest zakorzeniony w codzienności, w przyziemnych szczegółach interakcji społecznych, nawyków, rutynowych działań czy wiedzy praktycznej, w sferze życia, wydawałoby się, banalnej. Po drugie, kryzys wkomponowany w relacje między codziennością a niecodziennością dotyka tym samym formy i treści ich wzajemnych relacji, przy czym może się zakończyć na zmianie $z$ poziomu treści bez naruszenia formy. Po trzecie, wkomponowanie kryzysu w relacje między codziennością a niecodziennością stanowi też swoiste novum wobec dotychczasowych rozważań lokujących kryzys w tradycyjnych opozycjach: mikro-makro, jednostka-społeczeństwo itp.

Mirosława Marody i Anna Giza-Poleszczuk (2004, s. 18-24) traktują kryzys jako zarówno przyczynę, jak i skutek rozpadu więzi społecznych, a potwierdzenie takiego stanowiska można znaleźć w przywołanych wyżej klasycznych koncepcjach Durkheima czy Mertona. Rozpatrywanie kryzysu z punktu widzenia codzienności daje podstawy do odmiennego twierdzenia, mianowicie kryzys może sprzyjać wytwarzaniu nowych więzi i relacji. Stanowi bowiem pretekst do zmiany większych lub mniejszych fragmentów życia jednostki, upoważnia (a nawet zmusza) do podejmowania istotnych i nowych decyzji. Codzienność jako forma porządkowania praktyk społecznych wpycha w rutynowość (co w pewnym sensie sprzeciwia się ponowoczesnej wizji jednostki jako podmiotu, pozytywnie wartościującej własny wolny wybór), a jednocześnie szerszy kontekst makrospołeczny może ową bezproblemowość utrudniać (choćby przez skrępowanie jednostek wzajemnymi zależnościami). Kryzys redefiniuje życie codzienne, wprowadzając jednostkę w sferę nowych praktyk. Przy takim założeniu - może być wartościowany jako element pozytywny, a nawet pożądany.

\section{BIBLIOGRAFIA}

Begg David, Fisher Stanley, Dornbusch Rudiger, 2000, Ekonomia. Makroekonomia, tłum. różni, Polskie Wydawnictwa Ekonomiczne, Warszawa.

Berger Peter L., Luckmann Thomas, 1983, Społeczne tworzenie rzeczywistości, tłum. Józef Niżnik, PIW, Warszawa.

Durkheim Émile, 1999, O podziale pracy społecznej, tłum. Krzysztof Wakar, Wydawnictwo Naukowe PWN, Warszawa. 
Giddens Anthony, 2001, Nowoczesność $i$ tożsamość. „Ja” $i$ społeczeństwo $w$ epoce późnej nowoczesności, tłum. Alina Szulżycka, Wydawnictwo Naukowe PWN, Warszawa.

Goffman Erving, 2006a, Pierwotne ramy interpretacji, tłum. Marek Ziółkowski, w: Wspótczesne teorie socjologiczne, Aleksandra Jasińska-Kania, Lech Nijakowski, Jerzy Szacki, Marek Ziółkowski (red.), Scholar, Warszawa.

Goffman Erving, 2006b, Rytuat interakcyjny, tłum. Alina Szulżycka, Wydawnictwo Naukowe PWN, Warszawa

Goffman Erving, 2008, Człowiek w teatrze życia codziennego, tłum. Helena Datner-Śpiewak, Paweł Śpiewak, Wydawnictwo Aletheia, Warszawa.

Habermas Jürgen, 2005, Filozoficzny dyskurs nowoczesności, tłum. Małgorzata Łukasiewicz, Universitas, Kraków.

Luhmann Niklas, 2007, Systemy społeczne. Zarys ogólnej teorii, tłum. Michał Kaczmarczyk, Nomos, Kraków.

Manterys Aleksander, 1997, Wielość rzeczywistości w teoriach socjologicznych, Wydawnictwo Naukowe PWN, Warszawa.

Marody Mirosława, Giza-Poleszczuk Anna, 2004, Przemiany więzi społecznych. Zarys teorii zmiany społecznej, Scholar, Kraków.

Merton Robert K., 1982, Teoria socjologiczna $i$ struktura społeczna, tłum. Ewa Morawska i Jerzy Wertenstein-Żuławski, PWN, Warszawa.

Rosier Bernard, Dockès Pierre, 1987, Cykle ekonomiczne. Kryzysy i przemiany społeczne perspektywa historyczna, tłum. Marek Rekowski, PWE, Warszawa.

Schütz Alfred, 1982, Collected Papers II. Studies in Social Theory, Martinus Nijhoff, The Hague.

Schütz Alfred, 1984, Potoczna i naukowa interpretacja ludzkiego dziatania, tlum. Dorota Lachowska, w: Kryzys i schizma. Antyscjentystyczne kierunki $w$ socjologii wspótczesnej, wyb. Edmund Morzycki, PIW, Warszawa.

Simmel Georg, 2005, Socjologia, tłum. Małgorzata Łukasiewicz, Wydawnictwo Naukowe PWN, Warszawa

Szafraniec Krystyna, 1986, Anomia — przesilenie tożsamości: jednostka i społeczeństwo wobec zmiany, Wydawnictwo UMK, Toruń

Turner Jonatahn, 2006, Struktura teorii socjologicznej, tłum. Grażyna Woroniecka, Wydawnictwo Naukowe PWN, Warszawa

\section{EVERYDAY LIFE IN CRISIS}

\section{Summary}

The aim of this article is to demonstrate the relationship between everyday life and special conditions seen in the context of the concept of crisis. The authors define everyday life and special conditions as two opposing ways of experiencing social life, but their differentiation does not depend on their content but rather on form and manner of their perception/realisation in everyday life. This differentiation is described on the basis of the example of the concept of crisis, understood as the breakdown of everyday life and the consequent creation of special conditions. Based on contemporary examples, concerning to a large degree the social consequences of the breakdown of the economy, the authors represent crisis as a moment of renegotiating the principles of social life, the disruption of the routines and habits of everyday life and the transition into the unpre- 
dictability and reflexivity of social practices which characterize such special conditions. Attention is paid in particular to the concept of power, which takes on new meanings in the sociology of everyday life, differing from its institutional meaning, closer rather to "everyday power" which is realised in the framework of direct interactions in daily life.

\section{Key words/słowa kluczowe}

everyday life / codzienność; sociology of everyday life / socjologia życia codziennego; crisis / kryzys; power / władza; face-to-face interactions / interakcje bezpośrednie 